RESEARCH HIGHLIGHTS

\title{
Down in the depths
}

An obligate photosynthetic anaerobe found in deep-sea hydrothermal vents might photosynthesize by harnessing geothermal light rather than solar energy, according to recently published results.

Scientists have been exploring the microbiology of deep-sea hydrother-

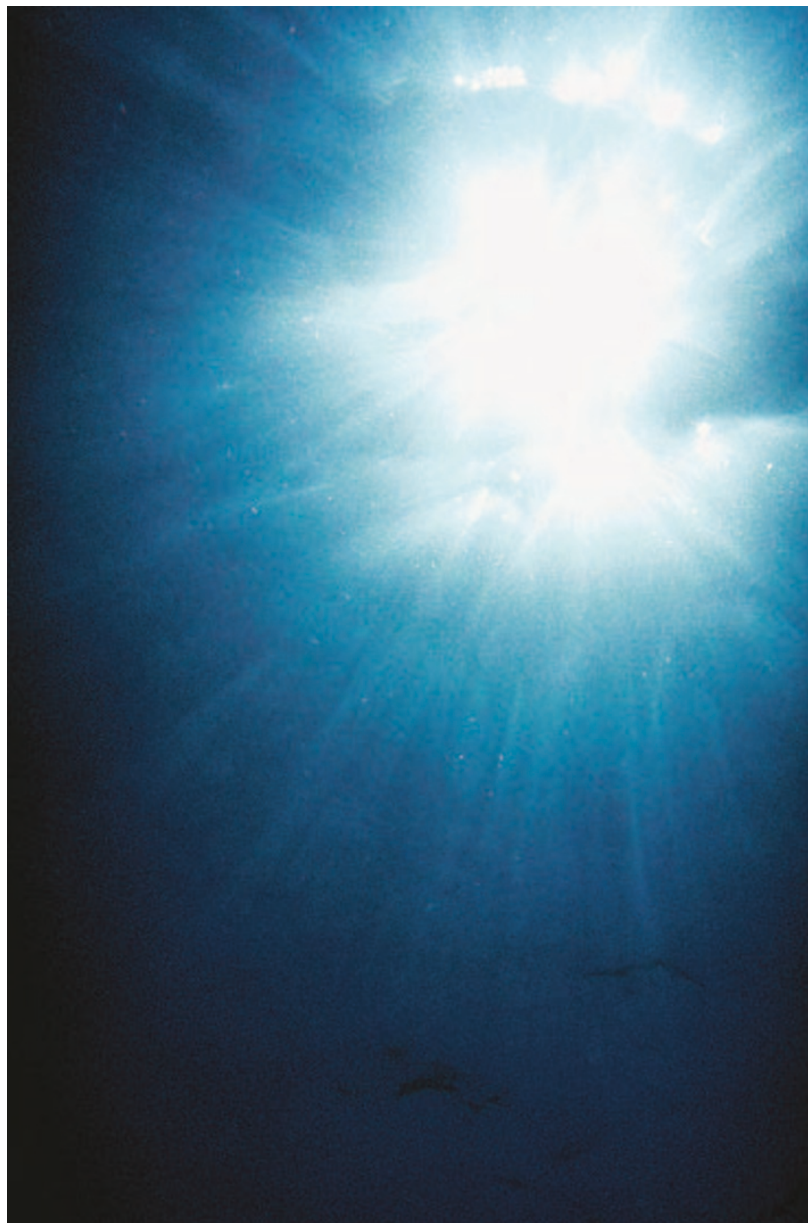

mal vents - geysers that form along volcanic mid-ocean ridges - using submersible vessels for almost 30 years. Until now, life in this environment was thought to depend on chemotrophic bacteria, although the identification of low-level illumination in the form of 'vent glow' gave a tantalizing hint that photosynthesis was a possibility.

Beatty et al. investigated whether geothermal illumination could support photosynthesis by analysing samples taken from the effluent plume of a type of vent known as a black smoker located at the East Pacific rise. Enrichment culturing yielded a non-motile bacterium that has been named GSB1. Analysis of the absorption and emission spectra of intact GSB1 cells isolated in pure culture - with major peaks at $\sim 750 \mathrm{~nm}$ and $\sim 775 \mathrm{~nm}$, respectively - indicated the presence of lightharvesting bacteriochlorophyll $c$.

Further analysis by electron microscopy revealed the presence of light-harvesting chlorosomes, structures that are commonly found in green sulphur bacteria. Light energy is transferred to the chlorosome reaction centre through the Fenna-Matthews-Olson (FMO) protein; PCR using FMO-specific primers amplified a 970-bp FMO segment from GSB1, and sequence analysis led the authors to conclude that GSB1 is a green sulphur bacterium related to the Chlorobium and Prosthecochloris genera. For growth, GSB1 requires anaerobic growth conditions, sulphur in the form of elemental sulphur or $\mathrm{H}_{2} \mathrm{~S}, \mathrm{CO}_{2}$ and light.

This identification of a green sulphur bacterium in a sample taken from a deep-sea hydrothermal vent not only suggests that photosynthesis can take place in the absence of sunlight but also once again illustrates the maxim that bacteria are the ultimate survivors.

Sheilagh Molloy

(2) References and links ORIGINAL RESEARCH PAPER Beatty, J. T. et al. An obligately photosynthetic bacterial anaerobe from a deep-sea hydrothermal vent. Proc. Natl Acad. Sci USA 102, 9306-9310 (2005) 